\title{
Improving Citizens' Participation in Local Government Planning and Financial Management in Ghana: A Stakeholder Analysis of the Sefwi Wiawso Municipal
}

\author{
Assembly \\ Ahenkan Albert, Bawole N J and Domfeh K A \\ Department of Public Administration and Health Services Management \\ P. O. Box LG 78, University of Ghana, Accra, Ghana. \\ Tel: +233246955818Ｅ-mail: aahenkan@ug.edu.gh/jnbawole@ug.edu.gh
}

Received: June 01, 2013 Accepted: June 13, 2013 DOI: 10.5296/jpag.v3i2.3782

\begin{abstract}
Ghana's decentralization concept was initiated to promote popular grassroots participation in the management and administration of local governance institutions for improved conditions of life. This is believed to be an important means to improving the effectiveness of service delivery and empower the local people to participate in the development processes that affect their lives. Despite this important role of local communities and stakeholders in the local governance processes, their involvement in decision making on planning, budgeting and financial management of local government agencies is only marginal. This low level of participation is one of the most structural challenges confronting Ghana's decentralisation process and local government financial management. Using Stakeholder Analysis, this paper examines the role and level of participation of stakeholders in planning, budgeting and financial management of the Sefwi Wiawso Municipal Assembly. The results of the study indicate that, there has been very little space for local participation and that most of the stakeholders lack proper understanding of the planning, budgeting and the financial management systems of the district assemblies. This lack of space for stakeholder participation has constrained the promotion of effective, responsive and responsible government at the local level for poverty reduction. Procedures and structures for community engagement in the monitoring and evaluation of development interventions seldom exist. The paper argues that an effective engagement of local communities and other stakeholders will enhance transparency and improve upon service delivery within the local government systems. A conscious effort to build capacities and create space for local engagement will enhance the efforts of decentralisation and fast track poverty reduction and national development in Ghana.
\end{abstract}

Keywords: local government, budgeting, finances, planning, community participation, stakeholders 


\section{Introduction}

Ghana's decentralization concept was initiated to promote popular grassroots participation in the administration of the planning, implementation, monitoring and delivery of services to improve the living conditions of the rural poor. This link between participation and local governance in Ghana has become an important means of improving the effectiveness of services and empowering the local people to participate in the development processes that affect their lives. Article 35(6)(d) of Ghana's 1992 Constitution urges the state to make democracy a reality by embarking on the decentralisation project to offer greater opportunities for greater citizen participation at all levels of local decision-making. Among the key reasons for Ghana's decentralisation process was therefore the desire to increase citizens' participation in local governance. This was a deliberate and concerted effort by the government to eradicate the economic, social, cultural and political challenges that contribute to poverty in the country. To effectively achieve this, the district assemblies are required to co-ordinate district level sectoral programmes/projects directed towards poverty reduction with the active participation of the local people. Consequently, the development planning and budgeting systems in Ghana have become bottom-up and the inputs of all stakeholders are expected to facilitate the process of integrating stakeholder interest into the planning and budgeting process at the district level.

It is significant to note that in all the attempts at decentralisation and local governance in Ghana before and after independence, the role of the citizen had been paramount albeit at different levels of zeal. Article 240 (2) (e) of the 1992 Constitution of Ghana demands that local people are afforded the opportunities to effectively participate in the governance of the district. Whereas arguments such as residence requirement qualification for candidacy, state sponsorship for local elections, and the non-partisan local electoral process have been adduced to illustrate how citizens participation is being pursued (Ahwoi 2010:166), evidence does not seem to support the reality of active citizens participation.

Participation has been largely electoral participation of the citizenry in local government and the incidence of effective participation of the citizenry in practice has been rather tokenistic. Restoring the confidence of the citizens in local government and the decentralised process in Ghana requires major attempts to drag in the citizens' to participate not only in elections but also in its active workings. In this regard, citizens' participation in planning and budgeting in particular, and financial administration in general has been recommended. Section 16 of the Local Government Act 1993 states that elected Assembly members are required to:

meet his [sic] electorate before each meeting of the District Assembly'; 'maintain close contact with his electoral area, consult his people on issues to be discussed in the District Assembly and collate their views, opinions and proposals . . . and present [these] to the District Assembly'; 'report to his electorate the general decisions of the District Assembly and its Executive Committee and the actions he has taken to solve problems raised by residents in his electoral area'. 
While normative arrangements exist for the involvement of local citizens, the practicalities of local and national conditions and the political gymnastics of actors have culminated in the interest of locals being subdued. This paper therefore seeks to investigate the realities of stakeholder participation in the planning and budgeting processes of the district assemblies in Ghana using the Sefwi Wiawso District Assembly as a case study. The rest of the paper is structured as follows: the next section reviews relevant literature on participatory planning and budgeting; followed by a discussion of the conceptual framework of mandatory and permissive stakeholder analysis. This is then followed by the methodology, findings and discussion of results. The final section provides some recommendations for policy actions to improve local participation in the planning and budgeting process of the district assemblies.

\section{Literature Review}

The implicit assumption that decentralisation will improve participation has remained contested as evidence from many decentralising countries point rather to a situation of only electoral participation (Devas and Grant 2003) which have also witnessed relatively low turnout (Ayee 2008; Ahwoi 2010). In cases where decentralisation has been a national reform agenda, the capacity of the citizens to become active actors and hence actively participate has been rather low plus limited opaque policy options offered to citizens to enable informed decision making. The ability of the citizens to participate between elections has been limited with prejudiced and sluggish consultation to say the least (Devas and Grant 2003). In some cases, central government pretends to be decentralising while limiting capacities to engage the citizens fully through deliberate withholding of power and resources (Crawford 2009). However, citizens' participation continues to take centre stage in citizens' empowerment debates. This is considered more critical at the local levels where decentralisation is expected give more space for the engagement of local populations. However, the call has been to have citizens engaged in substantive issues other than electoral participation. In this regard, the participation of citizens in planning and budgetary processes has been identified as a key strategy albeit controversial. In the next subsection, we take a look at participatory planning as an avenue to have citizens take a stake in local government affairs.

\subsection{Participatory Planning}

Modern democracies are better described as representative or indirect where citizens' involvement or participation is limited to the act of voting and deciding those who will rule on their behalf. This according to Wood (2004) centralises power into the hands of a few, thereby increasing the likelihood of incongruence between the preferences of citizens and their representatives as well as the possibility of corruption and abuse of power by the government. It also means that all citizens do not have equal opportunity to have their voices heard. Hence Forero-Pineda (2001) argues that participative theory is thus, concerned with addressing the unequal distribution of power and resources and its effect on the daily lives of people. Citizen participation is therefore fundamental to democracy and considered central to governance and for that matter good governance. UNDP (1997) identifies legitimacy and voice as critical elements of good governance and that participation and consensus orientation are two strands of the element. 
Participatory theory aims to enhance the egalitarian redistribution of power, resources and democratisation of the political process at both national and local level. Thus, theorists have argued for a broader involvement of citizens in political systems and decision making (Forero-Pineda, 2001). As captured by Berner (2001) citizen participation in the governance process has become popular and is considered ideal and healthy and that citizen apathy is hazardous to civic health. Berner, (2001) warned that whether or not the public uses the opportunity, keeping that option available is important in a democracy. To ensure authentic democracy therefore, citizen participation will ensure that there is a meaningful tying of programs to people (Spiegel, 1968).

Planning takes place within intricate and dynamic institutional environments influenced by socio-economic and environmental factors (Healey 2003). The global shift from government to governance and multilevel governance came along with it the concept of participatory planning meant to deepen democracy and to enhance decision making (Monno and Khakee 2012). Although PP is said to have been christened variously as 'collaborative planning', 'communicative planning', 'deliberative planning', 'consensus building' among others, the key essence is the objective to indicate how interactiveness is exuded within the planning processes (Gedikli 2009). If the end of PP is desirable, it must not be forgotten that the processes of ensuring PP schemes are quite political. Healey et al.(2008) doubt if PP has any drastic change effect. They wonder whether it is a strategy by government to reduce civic protest by getting popular participation and if this is so, what benefits will be served. PP could also be a scheme to take advantage of citizens to reduce costs in pursuance of elites self serving policies or it serves to legitimise democracy for the elites. PP have also been conceptualised as a way of "regularising urban conflicts" (Healey et al. 2008:379). Of course PP has also been attributed to impacts of the "social and environmental movement" of the 1960s which not only opened a new chapter in urban policy both in material and process terms but also came along with a corps of actors amenable to citizens voices, learned and supported their activities (Healey et al. 2008).

Although PP has been considered valuable in principle, there are concerns about its realities and the willingness of actors to adopt it wholeheartedly. Citizens are often denied real influence and seldom their concerns taken onboard as their participation is limited to information and consultation (Monno and Khakee 2012). This situation had been reported to probably be changing slowly in jurisdictions with pressure from donors, civil society and the media. Some arguments suggest that since the ability of citizens to push for more space in constrained, there must be increased pressure for vertical accountability (Devas and Grant 2003) but this is know to stifle initiatives for more citizens' participation. Agger and Löfgren (2008) have identified a number of variables in relation to the two elements of process and outcomes of PP. They argue that assessing PP processes should include an assessment of the variables of broad social grouping representation; right to express opinions; mutual respect by all actors; transparency and availability of information; the right to dissent; and capacity to influence the process. Following from this, they propose a framework for assessing PP. The "norms" as they call the elements of their framework are access, public deliberation, adaptiveness, accountability, and political identities. These norms are assessed along the lines of input-process-outcome stream. 
It is important to recognise that if citizens must have a say in how the finances of the local government get managed, they must as well be able to influence how the planning is done. Local government expenditure is based upon plans and therefore, if citizens participate in the planning of the district, they invariable will have made significant impact on the preparation of the budget and ultimately, on the expenditure of the district. Multilateral institutions and national governments as well as local government institution are increasingly interested in participatory mechanisms as part of a discourse clustered around public management concepts of good governance and public-private partnerships. From this perspective citizens' participation is viewed by the World Bank (2005) and Inter-American Development Bank (1997) as a way of increasing governmental accountability and transparency in public affairs in combination with budget strictness.

\subsection{Participatory Budgeting (Marquetti et al. 2012a)}

PB is a public decision making device that allows citizens to discuss and negotiate the allocation of public resources (Wampler 2007). It is considered a mechanism for "administrative incorporation, expanding participation and narrowing contestation (He 2011:122). It is defined broadly as "a form of participatory democracy in which citizens and civil society organizations have the right to participate directly in determining fiscal policy" (Marquetti et al. 2012b:63). It begun to receive increased attention after it was introduced in Porto Alegre in Brazil. In that context, it was a scheme to ensure that citizens had significant say in prioritising the items on the public expenditure list for municipal investments (Cleuren 2008). PB mechanisms are increasing with more demands for good and democratic governance. In this regard, it is considered to come along with a couple of features that should enhance space for citizens' participation but success rates are said to range from "highly successful to very weak" (Wampler 2007:22).

PB increases the space for discourse on governmental spending and sheds lights on the budgetary process which defuses the steam for patronage and corruption. It serves as a training platform for educating citizens in the games of negotiation and the skill of asserting their rights. The argument is also advanced that budget restrain is achieved when pressure is brought to bear on policymakers through the participatory processes. It has positive effects for the redistribution of resources to poor neighbourhoods, improved quality of public services, and budget transparency. It stimulates and increases the information flow towards the participants during the budget scheme in order to enable citizens to scrutinise municipal accounts and procedures (Brinkerhoff and Goldsmith 2003;Wampler 2007;Mullins 2007; Souza 2001a;Kluvers and Pillay 2009).

Although PB is expected to have implications for accountability, the decentralization of decision-making authority and empowerment, the implications are not automatic as these are influenced by socio-economic and political factors. Robinson (2003) argues that there exists very little systematic or comparative evidence worldwide whether increased citizens' participation generates better outputs in terms of public services. Getting participatory mechanisms to work requires the inclusion of various social groups (Sintomer et al. 2008), the management of which presents key challenges. This results from the fact that budgets are often reactive tools to satisfy political demands (Jermias and Setiawan 2008). Other times the 
capacity of participants to make significant inputs has been doubtful (Boon et al. 2012). In most cases, final outputs of participatory processes do not reflect the aspiration and views expressed by participants (Michels 2012).

In spite of these reservations about $\mathrm{PB}$, the practice is still being advocated for and various participatory schemes have been adopted in budgetary processes (Berner 2001) but whatever the method adopted, it is important to recognise environmental peculiarities (Souza 2001b). Among the PB strategies, public hearings are very popular but require that prospective participants make time to attend. To address this weakness, other less site specific schemes such as visits to local civic groups, town hall meetings, opportunities to speak at regular meetings, citizen advisory boards, mail-in coupons, coffeehouse conversations, telephone surveys, mail surveys, fax surveys, web sites/e-mail, visits to neighbourhood associations, and contact initiated by citizens have been adopted (Berner 2001; Franklin et al. 2009). It is however important to note that many of these strategies may not work in a developing country context. Mail and tele-related methods may not be appropriate in most developing countries where these services hardly function well. This requires investigation into identifying methods and strategies that will be most appropriate for involving citizens in participatory budgeting in these contexts.

\section{A conceptual framework: Stakeholder Analysis}

There have been debates over who qualifies to participate in participatory governance programmes such as $\mathrm{PB}$. This results from the nagging question of whether participants are a problem or solution in the scheme of solving development problems (Brinkerhoff and Goldsmith 2003). This is especially so when participation is perceived to bring in personal benefits either in material form or image enhancing (Boon et al. 2012). In ensuring that the right actors with the right interest are recruited to participate at the right stage and at the right time, stakeholder analysis is often considered the appropriate tool to adopt. In stakeholder analysis, several methods have been adopted but subjective models have presented challenges to good stakeholder analysis (Prell et al. 2009). What remains true is that irrespective of the type of analysis method, the span of interest in the project under consideration threatens an effective stakeholder analysis.

Stakeholder analysis in the public sector context should examine two perspectives: the mandatory and the permissive stakeholders. Mandatory stakeholders are those required by law to be stakeholders. In many policy and governmental actions, certain individuals and groups of persons are mandated to constitute core actors. These actors then cannot be neglected in the stakeholder engagement processes. These stakeholders are said to have "formal bureaucratic and political authority" and therefore have the legitimacy to make decisions (Gilson et al. 2012:166). Although many of these mandated stakeholders may not be personally affected by the policy, the institutions they represent may have significant interest in the outcomes of the policy. Permissive stakeholders are made of two types of stakeholders - interest wielders and interest advocates. Interest wielders constitute those stakeholders whose interests may be affected by a policy and for good governance purposes, are permitted to participate in the policy processes. Interest advocates on the other hand are those who purport to fight on behalf of the interest wielders who are incapable of fighting for 


\section{Macrothink}

themselves. Included in this later category of permissive stakeholders are civil society organisations who directly advocate on behalf of stakeholder or empower the stakeholders to hold duty bearers accountable. This paper adopts the mandatory-permissive framework as a guide in analysing the stakeholder participation in planning, budgeting and financial management of the district assemblies. In other words, the paper tries to identify how actors considered as mandatory to participate in the planning and budgetary process and how they get involved at the local level. It also tries to identify those actors who are permitted to participate and how they are involved or not.

\section{Methods and data collection Procedure}

\subsection{Overview of the Sefwi Wiawso District}

The Sefwi Wiawso District (SWD) lies in the Western Region between latitude $6^{\circ} 00^{\prime}$ and $6^{\circ} 30^{\prime}$ north and longitude $2^{\circ} 15^{\prime}$ 'and $2^{\circ} 45^{\prime}$ ' west. The district covers an area of $2,166.22 \mathrm{Km} 2$ comprising of $1,303.12 \mathrm{~km} 2$ off reserved and $863.10 \mathrm{~km} 2$ on reserved forests.

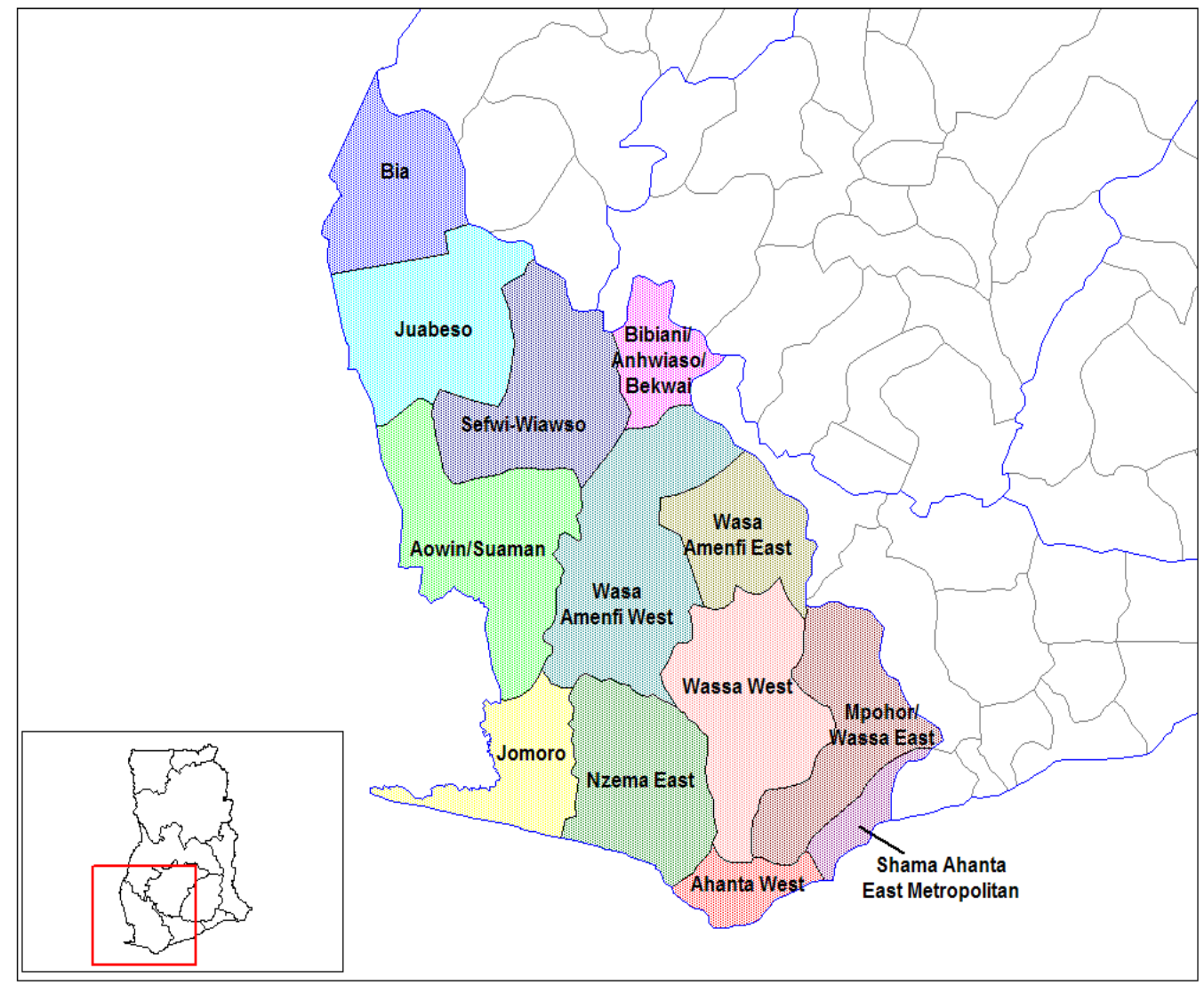

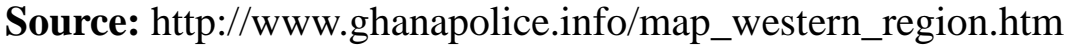

The district is the seventh largest in the Western Region of Ghana. Lying in the north-eastern part of the region. It is bordered to the north by Brong Ahafo Region; to the west, by Juaboso and Bia Districts, to the east by Bibiani-Bekawi District and by Aowin- Suaman to the south. The population of Sefwi Wiawso District is estimated at 148,950 comprising (51.3\%) males 
and $(48.7 \%)$ females (Ghana Statistical Service 2000) with an annual growth rate of $2.9 \%$. The dominance of male population in the district is the result of the influx of males from other parts of the country for farming, especially cocoa which is labour intensive and dominated by men and also the timber processing firms in the district recruit more males than females. The mainstay of the local economy is agriculture which employs 80 percent of the population.

\subsection{Study Approach, Design and Data Collection}

The case study design within the qualitative paradigm was used for this study. This is because it involves an in depth or intensive descriptions and analysis of a single unit or bounded system. This method was deemed appropriate because the researchers examine in detail, many features of a few cases at a point in time often in a qualitative form (Neuman, 2007). The qualitative research instruments used for this study were In-depth Interviews and Focus Groups Discussions. To facilitate this process, the researchers first identified the various stakeholders in the Sefwi Wiawso through workshops organised in May and June 2012. Stakeholder identification and analysis is best conducted using brainstorming techniques. This procedure is generally best in a workshop setting, with representatives of key participants. The participants first listed all parties which are likely to be affected by the development in the district, both positively or negatively, directly or indirectly. The stakeholders were grouped into five main interest groups. The groups include youth, women's groups, farmer-based organisations, civil society organisations, assembly members, opinion leaders and local authorities. Key informant interviews are qualitative in-depth interviews with people who have particular knowledge and understanding of the issues regarding the research topic or area of study. The purpose of the key informant interviews in this study was to collect information from a wide range of people including district planning officers, coordinating directors, community and opinion leaders. A total of 15 respondents participated in the in-depth interviews. They include a district planning officer, budget officer, finance officer, coordinating director, presiding officer, some assembly members and opinion leaders. In addition 4 FGDs were organised in four communities with assembly members, women groups, farmers and opinion leaders. FGD is a technique involving the use of in-depth group interviews in which participants are purposively selected from a representative sample of a specific target group. The purpose of focus group discussions is to gain knowledge about a particular topic or need by interviewing a group of people directly affected by the issue. The FGD generated information related to their knowledge in decentralisations, their participation in the planning, budgeting and implementation of development projects, and accountability in the district. The groups were selected based on similarity of socio-characteristics so that they would be comfortable talking to the interviewer and each other. To ensure reliability and validity of the data, it was triangulated with information collected from the key informants.

\section{Results and Discussion}

This section presents the results and discussion of the data generated through in-depth interviews and focus group discussions. This covers an overview of the planning and budgeting process of the district assembly, interest and power of stakeholders, community involvement in decision making, monitoring and evaluation of community development 
projects as well community involvement in transparency and accountability of the district assembly.

\subsection{Over view of the Planning and Budgeting processes of the District Assembly}

Planning is a vital component of the current system of district administration in Ghana. Planning and budgeting is done at the various levels of the district assembly concept. At the grassroots level, it starts with community involvement where the community members assume responsibility to contribute to their own development through assembly members and sub-district structures. Act 480 of the 1992 constitution offers the legal basis for every District Assembly to develop a focused plan that outlines strategic programmes to meet the development needs of the entire district (MLGRD, 2010). Each District Planning Coordinating Unit (DPCU) is supposed to plan and implement the Assembly's own plans within the framework of the national plan.

The planning has two phases. Stage one is the participation level at the local communities. This is done to identify the communities' problems and opportunities and also facilitates the engagement of all parties through public hearings. Stage two involves the synthesization and priority setting by the District Assembly of all the inputs from the Unit Committees and the local people before upward submission to the Regional Coordinating Councils and to the National Development Planning Commission (NDPC) which is the final body that ensures consistency and continuity in the framing and execution of development policy for the entire country. These initiatives are harnessed into the District Plan, which is directed into national strategic planning by the National Development Planning Commission. The DCD and the DPO indicated that each stage in the process and input capture involves consultations with the local people.

"We have observed that most of the people are either not interested in the process or not aware because the assemblymen are supposed to inform the entire community and to solicit their participation".

It was clear during the FGDs that most people are not to be aware of this process as reveal by the results of the FGDs. Before rural communities can make attempts to impact public policy, it is important that they have an understanding of the policy-making process itself

\subsection{Interest and power classification of stakeholders}

The stakeholder analysis identified five main stakeholders. The results of the FGDs and In-depth interviews revealed various levels of stakeholder interests and potential of each stakeholder to influence the planning and budget process of the district. The level of interest is the priority and importance the stakeholder attaches to the process of decentralisation and community development. The level of influence also depends on the quantity and type of resources and power the stakeholder can marshal to promote its position on participation. The results indicate that interests in the decentralisation processes of the district are very diverse. Table 1 indicates the various stakeholders, their level of interests and influence in the 
decentralisation process.

Table 1: Stakeholder Interest and Power to influence decentralisation process

\begin{tabular}{|l|l|l|}
\hline Stakeholder & Interests & $\begin{array}{l}\text { Power/level } \\
\text { of influence }\end{array}$ \\
\hline Youth & High & Low \\
\hline Farmers & Low & Low \\
\hline Women & High & Low \\
\hline Civil Society organisations & High & High \\
\hline Assemblymen & High & low??? \\
\hline Opinion Leaders & High & Low \\
\hline Local authorities & High & High \\
\hline
\end{tabular}

Source: FGD, 2012

The study reveals that the interest of youth in the development process of the district is high but with low power to influence the process. The assembly members who represent the community have also high interest in the community development but seems powerless with low level of influence. The most vulnerable identified groups are the women and farmers. The study reveals that there has been very little inclination towards the involvement of the rural women and farmers in the development process of the district. Although women have high interest in the development process of the district but with low power to influence decision making due to socio-cultural factors revealed during the FGD 3.

"Most of the issues affect us and our children so we are more interested in the development of the district. ......we fetch the water, grow the food crops, take care of the children but when they discuss things that affect us nobody consults us".

"Whatever the men agreed upon is okay for us. In this community when you are a woman and you question some issues you are branded as a witch". I for instance, had wanted to contest the district assembly elections three years ago to represent my electoral area at the district assembly but my husband objected to it and I stopped".

"Most of us cannot read nor write and therefore we don't understand how the work of the district assembly is done. Some of us even don't know the name of the District Chief Executive. They only inform us that a new DCE has been chosen. 
Youth engagement and participation is very crucial in local community development. They provide new ideas and voices that will stimulate enthusiasm and promote effective participation in local government process and structures. The interest of the youth in the development of the district is high but have low influence in decision making. However, the youth feel under represented with low voice and mistrust. A youth leader lamented:

"Master, the assemblymen hardly meet with us to brief us on the developments in the district. For instance a timber contractor was here to log in this community. The contractor got his permit to log in the forest here without our knowledge and when we asked he directed us to go the assembly and when we went to the Assembly nobody was willing to listen to us so we came back to block the contractor from logging and it became a big issue and I was put in police cells for three days.....since then most of the youth feel reluctant to talk about community development".

"Most of the chiefs and DCEs think we the youth are threat to their administration and therefore they do everything to block our participation. ...... the past DCE for instance never visited this community because he said the youth of this community do not respect".

The above is an indication of the challenges that youth face in participation. However, within the greater social framework of community participation in development process, youth may have expertise or interests in specific issues. As youth are brought into and connected with organizations and civic roles that they have traditionally been excluded from, they can participate in active and equal decision making at multiple levels.

Another important stakeholder whose interest in the development of the district is very high are the Assemblymen. It was clear from the FGDs that they have the power to influence the process. The only challenge is that most of the members lack the advocacy and lobbying skills. Most are illiterates and cannot properly review development documents.

The DPO stated that:

"Although the assemblymen have high interest in the development projects that affect their communities', the problem is that most of them are not able to influence the process because most of them when they come to assembly meetings they cannot air their views. Some of them do not bring any input from their constituents"

Another important obstacle to the full participation of the assemblymen is lack of information. Underpinning greater public participation and accountability is the right of the public to information. Without the public's access to information, the level to which citizens can be an integral part of the governance system is stalled. Public access to information can be equated with transparency and this is a great antidote for many types of corruption and malpractice in 
public administration. The FGDs among the assemblymen reveal that most of them feel that access to information about the district's programmes and projects is difficult.

As an assemblyman I can tell you that the award of contract for some of the development projects in the district is not transparent. There are a number of development projects in the district that I don't know how they were awarded to contractors". When you demand for the cost of project they will not tell you. If I find it difficult to understand some of the process how can a community member understand it.

If you are an assemblyman and not in the ruling party you do not have access to lot of information. They won't even tell you. This affects our ability to effectively monitor development projects in the district.... a lot of people have become to contractors overnight because they are party loyalists and therefore they should be compensated. That is why most of our projects are poorly executed.

The planning process they talk about. master even if you bring some views from your electoral area they decide to take or leave it. Most of our ideas are not factored into the planning. .....also some of the community members when you invite them for community meeting they refuse and tell you the assembly has nothing to offer them. I am even confuse of the process myself. What I can say is that we are not well informed ourselves as assemblymen.

As Oduro (2010) notes, an informed citizenry is capacitated to better advocate for accountability of public officials on their conduct and on decisions made on matters affecting the public such as infrastructural development and service delivery. The study reveals that generally the level of participation and influence among the stakeholders in the district is low because most of the people, particularly the farmers, youth, women and opinion leaders lack proper understanding of the planning and budgeting systems of the district assemblies which are necessary for the promotion of an effective, responsive and responsible government at the local level. In addition they lack effective advocacy and lobbying skills and therefore they are unable to effectively participate in the process.

\subsection{Community Involvement in Planning and Budgeting in the District}

Although, the concept has the potential to promote local democracy, enhance public policy making, improve service delivery, and poverty reduction, it has not adequately addressed equal and reciprocal partnership between the district assemblies and the local population. Discussions with the DCD and DPO reveal that although the planning processes of the district assembly involve the local population in decision making at various level, the challenge is that the participation of the local population through the town hall meetings and Unit Committees has not been effective. DPO intimated that: 
"In all these stages we expect the community members to be actively involved to ensure that their views and needs are captured in the district planning".

"There is also a problem of who represents the community in engagement processes. How does assembly balance the authority of the traditional leaders, assembly members and community members with the one that comes from broad community participation?. These are issues we need to understand"

The DCD confirms this in the following statements

"Although the district has made some level of progress in engaging the citizens to participate in the planning and budgeting process, the district seems to be lacking in the area of participatory planning, which is one of the key components of decentralization". "Our challenge is that most assembly members do not consult their constituents. Most Unit Committees in the district are not functioning ... they are only on paper".

The results of FGDs also indicate that there has been very little inclination towards the involvement of the local people during the planning and budgeting processes of the of the district assembly. The participation of local people is very minimal and in some cases community members were not even aware of the process at all. Most of them have never heard about any community hearing aiming at soliciting their inputs for development projects that concern them.

"We are not aware of this process. Maybe it is on paper but in practice they never organised this kind of meeting in my community”.

"They said we are the most important primary stakeholders in the decentralization process but our assemblymen do not disseminate the outcomes of assembly meetings in the communities and vice versa".

Although members of the District Assembly and the Sub-District Councils are required to collate and analyze in detail all the major problems of their communities to facilitate the formulation of programmes, projects and activities, and also mobilize community members, and facilitate the needs assessment in the communities during community dialogue meetings for onward submission to the District Assemblies most members are not doing this. Discussion with some assemblymen during the FGD shows that there are a number of logistical and capacity challenges confronting the assemblymen which make it difficult for them to function effectively. Some participants of FGD (5) said.

"I am an assemblyman overseeing about 15 communities scattered all over the place. I don't 


\section{Macrothink}

Journal of Public Administration and Governance

ISSN 2161-7104

2013, Vol. 3, No. 2

even have motor bike to go round to meet them. Recently the government provided us motor bikes to help our work and even that to fuel the motor bike, master is a problem. The assembly work is voluntary work. You see the problem?".

"Most of our fellow assemblymen are illiterates. They can't contribute in the assembly though some have genuine problems"...during assembly meetings they do not talk but after the meeting then you will realise that they have issues but could not raise them"

The FDG (4-SCO) agrees:

"It is important that the communities are educated to elect Assemblymen who are educated and knowledgeable in the district assembly concept to be able to represent their views".

"For assemblymen to play an active role in the decentralisation process, it is necessary that they have access to resources and their capacity need to be built".

Inadequate resources and capacity can negatively impact a rural community's ability to effectively influence policy development compared to other players in the policymaking process. Serious consideration must be given to the full implementation of the sub-district structures to facilitate information dissemination, community engagement and participation of the local communities to ensure that community development reflects the needs of the people as opined by some during the FGD (2).

"We know what we need as community but sometimes the assembly will not consult us on things that concern us. Did you see the KVIP in this town?... they brought it unannounced, the people patronised it when it was new but now nobody uses it again because they prefer the traditional type we use to dig and maintain ourselves".

"The assembly gave us this borehole. Initially they never mentioned about user fees. After the construction they told us to pay when we fetch water. Now some people in the community have refused to use it. They still prefer to fetch from the stream instead of paying for this water".

"For me as farmer, who cares about my views? But we also have something that can be good for development of this district”. 
"We have unit committee members who are to discuss the development needs on behalf of the community and also carry our inputs to the assembly but the problem is that most of them do not themselves understand the process".

"I would say that we as a community do not have a say in the assembly because although we elected an assemblyman but he is a teacher and resides in Kumasi. He only come to this community when the assembly is meeting and after that he goes back to Kumasi".

The relationship between the local communities and the district assembly is strained by the community perception that the assembly do not understand rural issues and impose their development programmes that negatively affect them. From the perspective of the community members, the attitudes and action of the local authorities have created barriers to working together to improve the lives of the people. The community members often perceive the district's priorities and interventions as not things that they need.

\subsection{Transparency and Accountability in district Assembly}

Transparency and accountability are critical for the efficient functioning of the district assemblies and for fostering social well-being. The district assemblies are accepted by ordinary people as the institution to look up to for most of their basic needs. It is therefore important that the assemblies ensure transparency and accountability and good governance. An opinion leader decried the pervasive corruption in the district assembly in the following words:

"There is too much corruption my brother...too much stealing...they connive with the contractors. Too much waste in the system, lack of cash control, poor procurement and purchasing practices, award of project contracts. These things can be minimized if proper measures were put in place but by who".

IDI (4-SCO) suggests:

"Community members should be empowered to have access to information, budget monitoring, and expenditure monitoring, and tracking of development projects. This would make the assembly accountable. We as an NGO should also participate actively in monitoring spending by the district assemblies, especially in the execution of contracts".

The process of enhancing access to information and public accountability for enhancing citizens' participation is going to be complex. However, they remain important elements in the promotion of transparency and accountability. There is the need for civil society organisations and community members to help promote transparency and accountability by 
focusing attention on corrupt practices at all levels of governance, including the community leaders and not to concentrate solely on the assembly officials.

Some of the chiefs and assembly members are corrupt. We need to check them not only the district assembly. ...... also the assembly's process of engagement could be very effective if the assembly members have the capacity and lobbying skills".

"The assembly is supposed to be a place for information but whenever you request for any information from the assembly regarding accountability or about the implementation project in your community they see you as litigant and nobody listens to you".

The knowledge about the current and future needs of the people in a district is very vital in development planning processes. It can inform decision-makers about the critical decisions regarding the kind of interventions required by the district assembly to speed up development project and to reduce poverty. Most of the representatives of the communities do not understand the process of planning, budgeting and financial management and decision making processes in the district. To achieve effective inclusiveness, there must be greater responsiveness on the part of elected and appointed assembly members.

\subsection{Structures for community engagement in Monitoring of development projects}

The community engagement process means working with and through constituents to achieve common goals. The study reveals that at the district assembly level the clear procedures and structures for community engagement in the monitoring and evaluation of development interventions seldom exist though some structures for promoting community engagement during planning processes. There are no clear structures for community involvement in the monitoring of development interventions in the district. The FGD discussions reveal issues such as poor relationships with the community members, mistrust and perceived lack of capacity on the part of the rural population in the monitoring and evaluation of development projects.

FGD (3) lamented:

"What I can say is that the assembly has not been able to establish good relationships and trust with the leadership in the communities so as to create effective processes for mobilizing the community". Master, if the process is not transparent how you can trust the system?. They think we do not know anything.... we can monitor the contractors to make sure they build schools, clinics or any other project very well. Some officials of the assembly connive with the contractors to steal project funds. They think we don't know.

However, the DCD disagrees:

"good relationship with communities is the best option but you see most often it also creates 
tension between communities and district assembly because of mistrust. Most of the assemblymen are not able to brief community members about projects in their communities....some them even accuse the assembly of conniving with contractors to inflate project costs but this is not true". This is because they don't understand the bidding process and other issues therefore give different interpretations to the implementation of projects".

While the local assembly interventions certainly affects communities and vice versa, there is a limit to the engagement and influence local assembly can have with communities. The process demands that those implementing the engagement processes communicate with community leaders and members who have diverse backgrounds, values, priorities, and concerns. Structures and processes that mediate communication between government and communities are crucial to engagement (OECD, 2001).

\section{Policy Recommendations}

This section recommends some policy strategies and actions that would better support citizen participation in the district assembly planning and budgeting in Ghana.

\subsection{Review of the budgetary process}

To enhance PB, the budgetary cycle must change to allow for the time spent on consultations. It is important to realise that actors need to know the budgetary cycle and be prompted to make submissions at the right time to enable the development of proposals for consultation. This should be taken into consideration the geography of the country. In this regard, it is important to give adequate time for districts with difficult to reach terrains to be able effective engage their constituents before plans and budgets are prepared. The ministry of finance should also require evidence of public consultation before budgets are approved for funding.

\subsection{Capacity issues of stakeholders}

Participation is a two-way affair. When space is given for participation, it is important for the participants to have the capacity to engage the duty bearers. Since the capacity of both assembly members and citizens is low, it is important for the assemblies to invest in developing their capacity. Assemblies stand to benefit with empowered and capacitated citizens as this would not only make their work easy, it will also create awareness on the work of the assemblies and contribute to enhancing their revenue drive.

\subsection{Open Government through local Radio}

Ghana now has a very vibrant media landscape especially local radio stations. This can be exploited by the Assemblies and civil society organisations to organise open government programmes to discuss the assembly planning systems and budgets and seek the inputs of listeners and contributors through phone-ins. These programmes will have better reach if they are held in the local languages. Another form of open government that will serve especially the rural communities would be cinema van shows for communities and market days. District assemblies can document their programmes on video and show these in cinema vans. The National Council for Civic Educations and the Information Services Department could play key roles in achieving these. 


\subsection{Election of DCEs}

Arguments have been made elsewhere that the election of the DCE would help to improve the workings of the assemblies. We would like to add our voice to this call and advocate for this to be done. The wisdom is this move is that the campaigns for election by contestants would bring out issues that ordinary citizens would normally not be told. It would also ensure that the DCE aspirants present themselves for scrutiny by the small critical mass of the citizens who care about the local government system.

\subsection{Involvement of Chiefs in Planning and Budgetary reviews}

For a long time, the chiefs have been kept on the fringes of local government system with very minimal involvement. At this point, it is recommended that chiefs should made part of the planning reviews and budget hearings. This way, the chief could hold the local governments accountable and report to their subjects the outcomes of such hearings. Chiefs still command some respect and could use their traditional cultural functions such as festival times to hold durbars where the local government could address the citizens.

\subsection{Civil Society Advocacy and Involvement}

Civil society and NGOs have a significant role to play in keeping the assemblies and their officials in check through advocacy campaigns and capacity building programmes to help enhance the capacity of key stakeholders. Advocacy and lobbying may have significant influence on the behaviours of the assembly officials.

\subsection{Accounts Audit Hearings}

Another avenue for more public engagement and accountability could be through accounts audit hearings in the nature of what the public accounts committee of Parliament does. Open audit hearings would provide citizens opportunities to get informed about how their monies have been used. These could be organised for the various traditional areas to ensure that as many people as possible get to participate in them.

\section{Conclusion}

Whereas the arguments in the literature and from the rhetoric of politicians are concerned, has underscored the need for local government structures and the capacity of the people to be strengthened at the district level to make the local government system more practical and meaningful in improving the welfare of the people. This lack of space for stakeholder participation has constrained the promotion of effective, responsive and responsible government at the local level for poverty reduction. Procedures and structures for community engagement in the monitoring and evaluation of development interventions seldom exist. The paper concludes that an effective engagement of local communities and other stakeholders will enhance transparency and improve upon service delivery within the local government systems. There is the need for progressing of engagement beyond consultation by developing a more effective engagement processes in the district. There should therefore be conscious effort to build capacities of local people particularly the key stakeholders to create space for local engagement so as to enhance the efforts of decentralisation and fast track poverty reduction in the district and Ghana as a whole. There is the need to also facilitate and equip 
assembly members with understanding of the planning and budgeting systems of the district assemblies and to improve their lobbying and the advocacy skills.

\section{References}

Agger, A. \& Löfgren, K. (2008). Democratic Assessment of Collaborative Planning Processes. Planning Theory, 7(2), 145-164.

Ahwoi, K. (2010). Local Government and Decentralisation in Ghana. Accra: Unimax Macmillan Ltd.

Ayee, J. R. A. (2008). The Balance Sheet of Decentralization in Ghana

Foundations for Local Governance. In: Saito, F. (ed.). Physica-Verlag HD.

Berner, M. (2001). Citizen Participation in Local Government Budgeting. Popular Government, Spring(2001), 23-30.

Boon, E., Bawole, J. N. \& Ahenkan, A. (2012). Stakeholder participation in community development projects: an analysis of the quadripartite model of the International Centre for Enterprise and Sustainable Development (ICED) in Ghana. Community Development, 1-17.

Brinkerhoff, D. W. \& Goldsmith, A. A. (2003). How Citizens Participate in Macroeconomic Policy: International Experience and Implications for Poverty Reduction. World Development, 31(4), 685-701.

Cleuren, H. (2008). Administrating Participatory Budgeting in Porto Alegre. Street-level Officials and Organisational Preconditions. Revista Chilena de Administración Pública, 12 (Diciembre 2008), 19-41.

Crawford, G. (2009). 'Making democracy a reality'? The politics of decentralisation and the limits to local democracy in Ghana. Journal of Contemporary African Studies, 27(1), 57-83.

Devas, N. \& Grant, U. (2003). Local government decision-making-citizen participation and local accountability: some evidence from Kenya and Uganda. Public Administration and Development, 23(4), 307-316.

Franklin, A. L., Ho, A. T. \& Ebdon, C. (2009). Participatory Budgeting in Midwestern States: Democratic Connection or Citizen Disconnection? Public Budgeting \& Finance, 29(3), $52-73$.

Gedikli, B. (2009). The Role of Leadership in the Success of Participatory Planning Processes. European Urban and Regional Studies, 16(2), 115-130.

Gilson, L., Erasmus, E., Borghi, J., Macha, J., Kamuzora, P. \& Mtei, G. (2012). Using stakeholder analysis to support moves towards universal coverage: lessons from the SHIELD project. Health Policy and Planning, 27(suppl 1), i64-i76.

He, B. (2011). Civic engagement through participatory budgeting in China: Three different logics at work. Public Administration and Development, 31(2), 122-133.

Healey, P. (2003). Collaborative Planning in Perspective. Planning Theory, 2(2), 101-123.

Healey, P., Booher, D. E., Torfing, J., Sørensen, E., Ng, M. K., Peterson, P. \& Albrechts, L. 
(2008). Civic Engagement, Spatial Planning and Democracy as a Way of Life Civic Engagement and the Quality of Urban Places Enhancing Effective and Democratic Governance through Empowered Participation: Some Critical Reflections One Humble Journey towards Planning for a More Sustainable Hong Kong: A Need to Institutionalise Civic Engagement Civic Engagement and Urban Reform in Brazil Setting the Scene. Planning Theory \& Practice, 9(3), 379-414.

Jermias, J. \& Setiawan, T. (2008). The moderating effects of hierarchy and control systems on the relationship between budgetary participation and performance. The International Journal of Accounting, 43(3), 268-292.

Kluvers, R. \& Pillay, S. (2009). Participation in the Budgetary Process in Local Government. Australian Journal of Public Administration, 68(2), 220-230.

Marquetti, A., Schonerwald da Silva, C. E. \& Campbell, A. (2012a). Participatory Economic Democracy in Action. Review of Radical Political Economics, 44(1), 62-81.

Marquetti, A., Schonerwald da Silva, C. E. \& Campbell, A. (2012b). Participatory Economic Democracy in Action. Review of Radical Political Economics, 44(1), 62-81.

Michels, A. (2012). Citizen Participation in Local Policy Making: Design and Democracy. International Journal of Public Administration, 35(4), 285-292.

Monno, V. \& Khakee, A. (2012). Tokenism or Political Activism? Some Reflections on Participatory Planning. International Planning Studies, 17(1), 85-101.

Mullins, R. D. (2007). Local Budget Process. In: Anwar, S. (ed.) Local Budgeting Washington DC: The World Bank.

Prell, C., Hubacek, K. \& Reed, M. (2009). Stakeholder Analysis and Social Network Analysis in Natural Resource Management. Society \& Natural Resources, 22(6), 501-518.

Sintomer, Y., Herzberg, C. \& RÖCke, A. (2008). Participatory Budgeting in Europe: Potentials and Challenges. International Journal of Urban and Regional Research, 32(1), 164-178.

Souza, C. (2001a). Participatory budgeting in Brazilian cities: limits and possibilities in building democratic institutions. Environment and Urbanization, 13(1), 159-184.

Souza, C. (2001b). Participatory budgeting in Brazilian cities: limits and possibilities in building democratic institutions. Environment and Urbanization, 13(1), 159-184.

UNDP. (1997). Governance for sustainable human development: a UNDP policy document [Online]. New York: UNDP. [Accessed 19/3/ 2012].

Wampler, B. (2007). A Guide to Participatory Budgeting. In: SHAH, A. (ed.) Participatory Budgeting. Washinton DC: World Bank. 